\title{
Mitochondrial DNA Variation of Leber's Hereditary Optic Neuropathy in Western Siberia
}

\author{
Elena Starikovskaya ${ }^{1, *}$, Sofia Shalaurova ${ }^{1}$, Stanislav Dryomov ${ }^{1}$, Azhar Nazhmidenova ${ }^{1}{ }^{1}$, \\ Natalia Volodko ${ }^{2}$, Igor Bychkov ${ }^{3}$, Ilia Mazunin ${ }^{4} * *$ (i) and Rem Sukernik ${ }^{1}$ \\ 1 Laboratory of Human Molecular Genetics, Institute of Molecular and Cellular Biology, SBRAS, \\ Novosibirsk 630090, Russia; sofigold@listu.ru (S.S.); stasundr@gmail.com (S.D.); \\ deviliona@yandex.ru (A.N.); sukernik@gmail.com (R.S.) \\ 2 Department of Pediatrics, University of Alberta, Edmonton, AB T6G 2R3, Canada; \\ michael.brown@ualberta.ca \\ 3 Novosibirsk Branch of S.N. Fedorov NMRC “MNTK Eye Microsurgery”, Moscow 127486, Russia; \\ fgu@mntk.ru \\ 4 Center of Life Sciences, Skolkovo Institute of Science and Technology, Skolkovo 121205, Russia \\ * Correspondence: estariko18@gmail.com (E.S.); I.Mazunin@skoltech.ru (I.M.)
}

Received: 23 October 2019; Accepted: 2 December 2019; Published: 4 December 2019

\begin{abstract}
Our data first represent the variety of Leber's hereditary optic neuropathy (LHON) mutations in Western Siberia. LHON is a disorder caused by pathogenic mutations in the mitochondrial DNA (mtDNA), inherited maternally and presents mainly in young adults, predominantly males. Clinically, LHON manifests itself as painless central vision loss, resulting in early onset of disability. The epidemiology of LHON has not been fully investigated yet. In this study, we report 44 genetically unrelated families with LHON manifestation. We performed whole mtDNA genome sequencing and provided genealogical and molecular genetic data on mutations and haplogroup background of LHON patients. Known "primary" pathogenic mtDNA mutations (MITOMAP) were found in 32 families: m.11778G $>$ A represents 53.10\% (17/32), m.3460G $>$ A $-21.90 \%$ (7/32), m.14484T $>C-18.75 \%(6 / 32)$, and rare $\mathrm{m} .10663 \mathrm{~T}>\mathrm{C}$ and $\mathrm{m} .3635 \mathrm{G}>\mathrm{A}$ represent $6.25 \%(2 / 32)$. We describe potentially pathogenic m.4659G $>\mathrm{A}$ in one subject without known pathogenic mutations, and potentially pathogenic m.6261G >A, m.8412T>C, m.8551T>C, m.9444C > T, m.9921G >A, and m.15077G >A in families with known pathogenic mutations confirmed. We suppose these mutations could contribute to the pathogenesis of optic neuropathy development. Our results indicate that haplogroup affiliation and mutational spectrum of the Western Siberian LHON cohort substantially deviate from those of European populations.
\end{abstract}

Keywords: LHON; Siberian population; ancient mutation; specific genetic background

\section{Introduction}

Leber's hereditary optic neuropathy (LHON) is a form of hereditary disorder caused by pathogenic mutations in mitochondrial DNA. These mutations are non-synonymous, and affect genes coding for different subunits of complex I of the mitochondrial respiratory chain. The occurrence of such kinds of mutations in mtDNA subunits leads to dysfunction of the electron transport, increased reactive oxygen species production, and defective ATP synthesis [1-3]. Retinal ganglion cells are highly susceptible to death during LHON progression, because of their high sensibility to disrupted ATP production and oxidative stress [4]. Therefore, LHON is usually painless, acute, or subacute, central visual loss of one or both eyes, which results in early onset of disability. The onset of Leber's hereditary optic neuropathy is relatively rare and has better visual prognosis. The peak age of onset of visual loss among 
LHON carriers is $20-30$ years old [5]. In some cases, LHON patients have been reported as having additional neurologic, cardiac, and endocrine disorders [6-8]. Leber's disease is maternally inherited and manifests itself in youth predominantly ( $50 \%$ of man and $\sim 10 \%$ of women). Interestingly, this sex predilection cannot be explained by the principles of mitochondrial inheritance [4].

At the present time, a number of mtDNA point mutations have been described, but the most prevalent are m.3460G $>$ A, m.11778G $>$ A, and m.14484T $>C$, accounting for about $90 \%$ of cases of LHON worldwide. The prevalence of each mutation varies among different populations, but the average is 69-92\% for m.11778G $>$ A, and 3-19\% for m.14484T $>C$ and m.3460G $>$ A [9-14]. However, there are significant deviations from the average in some populations, for example, among French Canadians $87 \%$ of cases are due to $\mathrm{m} .14484 \mathrm{~T}>\mathrm{C}$ as a result of a founder effect [15]. Moreover, phenotypic expression of these primary mutations has been found to vary in different populations and different pedigrees. This incomplete penetrance suggests that other factors, such as mtDNA haplogroup background, nuclear genetic background, and environmental factors, may influence the modulation of phenotypic expression and severity of the disease [16-18].

Consequently, the worldwide prevalence of LHON varies in different populations and is unknown for the majority of them. This prevalence is estimated to range between 1:30,000 and 1:50,000 [19,20]. The epidemiology of LHON has not been fully investigated in Russian Federation, and our previous studies included the description of isolated cases [21-23]. Hence, in the present study, we report 44 genetically unrelated LHON families, performed whole mtDNA sequencing, and provide molecular genetic data on mutations and the haplogroup background of LHON patients in the Western Siberian population.

\section{Materials and Methods}

\subsection{Subjects}

This study was approved by the Ethics Committee IRB 00001360 affiliated with Vector State Research Center of Virology and Biotechnology (SRC VB Vector), Novosibirsk, Russian Federation. The total number of subjects in the study is 168 individuals from 44 unrelated families ( 85 affected and 83 healthy carriers), including 17 cases from our previous studies [21-23]. The clinical follow-up of LHON patients has been carried out by the Novosibirsk Branch of Federal Eye Microsurgery Department since 1997, conducted by one of the authors. The clinical diagnosis was based on a combination of symptoms and signs: painless acute or subacute central vision loss; fundus changes; and visual field abnormality, such as pseudopapilledema, optic nerve atrophy, and central or centrocecal scotoma. All the individuals made an informed decision to take part in the study and provided written consent. Family history was taken in each case to identify maternal inheritance of symptoms. The complete mtDNA genomes were sequenced for the family's probands, and for the other individuals the certain mutations were confirmed by sequencing of associated mtDNA regions.

\subsection{MtDNA Analysis}

Whole peripheral blood samples were collected from the donors in $10 \mathrm{~mL}$ Vacutech EDTA tubes. Total DNA was extracted from a buffy-coat layer using the SileksMagNA-G Blood DNA Isolation kit, according to the manufacturer's protocols. The complete sequencing procedure entailed PCR amplification of 22 overlapping mtDNA templates [24], which were sequenced in both directions with BigDye 3.1 terminator chemistry (PE Applied Biosystems, Foster City, CA, United States). The trace files were analyzed with Sequencher (version 4.5 GeneCode Corporation) software. To perform capillary electrophoresis on an ABI Prism 3130XL DNA Analyzer, we used core facilities of the "Genomika" Sequencing Center (SBRAS, Novosibirsk, Russian Federation). Variants were scored relative to the Reconstructed Sapiens Reference Sequence, RSRS [25]. MtDNA haplotypes were identified following the nomenclature suggested by the PhyloTree Build 17 [26]. Forty-two mitochondrial genomes obtained through this study were deposited in GenBank with accession 
numbers MN413201-MN413242. Two genomes, EU807741.1 and EU807742.1, had been deposited to the GenBank earlier [21].

\subsection{Penetrance Analysis}

We determined penetrance as the proportion of affected individuals from all maternally related family members using family pedigrees [19]. Values for both men and women were calculated separately.

\subsection{Analysis of Pathogenicity for Non-Synonymous Mutations}

To make sure that the revealed non-synonymous mtDNA mutations were not sequencing errors or to not point out to general population polymorphisms, and in turn to find out the disease-associated polymorphisms among those published earlier, we used several databases: MITOMAP [27]; mtDB (Human Mitochondrial Genome Database, containing 2704 human mitochondrial genomes) [28]; and HmtDB (Human Mitochondrial DataBase), which contains 32922 human mitochondrial genomes [29]. To assess the possible pathogenicity of these mutations, and to predict whether a protein sequence variation affects protein function, we used the following web applications: MutPred 1.2 [30], MutPred 2 [31], PolyPhen-2 [32], PROVEAN (Protein Variation Effect Analyzer) [33], and SIFT (Sorting Intolerant from Tolerant) [34]. All the sources are provided in the public domain.

\section{Results}

From $44 \mathrm{LHON}$ families, 32 harbored a primary mutation; the results are shown in Table 1 . Among families with a primary mutation, the $\mathrm{m} .11778 \mathrm{G}>\mathrm{A}$ represented $53.10 \%(17 / 32), \mathrm{m} .3460 \mathrm{G}>\mathrm{A}$ was $21.90 \%$ (7/32), and $\mathrm{m} .14484 \mathrm{~T}>\mathrm{C}$ represented18,75\% (6/32). Rare m.10663T $>C$ and $\mathrm{m} .3635 \mathrm{G}>\mathrm{A}$ represented $6.25 \%(2 / 32)$ of the families.

Table 1. Summary data for examined Leber's hereditary optic neuropathy (LHON) and LHON-like (without primary mutations) families. Age of onset of visual loss vary between families/patients; the peak age of onset is $\sim 20-30$ years old. Some families were published previously * [23]; ** [22]; ${ }^{* * *}$ [21].

\begin{tabular}{|c|c|c|c|c|c|c|}
\hline No. & $\begin{array}{l}\text { Family } \\
\text { Name }\end{array}$ & $\begin{array}{l}\text { Ethnicity in } \\
\text { Maternal Line }\end{array}$ & $\begin{array}{c}\text { Number of } \\
\text { Examined } \\
\text { Individuals } \\
\text { (Affected/Healthy) }\end{array}$ & $\begin{array}{c}\text { Family } \\
\text { History of } \\
\text { Visual Loss }\end{array}$ & $\begin{array}{c}\text { Primary } \\
\text { LHON } \\
\text { Mutation } \\
\text { (MITOMAP) }\end{array}$ & $\begin{array}{c}\text { mtDNA } \\
\text { Haplogroup }\end{array}$ \\
\hline 1 & L18* & Altaian & $4(2 / 2)$ & No & $\mathrm{m} .3460 \mathrm{G}>\mathrm{A}$ & D4p \\
\hline 2 & $\mathrm{~L} 24$ * & Tuvinian & $19(7 / 12)$ & Yes & m.3460G $>A$ & C5d1 \\
\hline 3 & $\mathrm{~L} 25 * * *$ & Russian & $5(3 / 2)$ & Yes & m.3460G $>A$ & D5a2a2 \\
\hline 4 & L41 & German & $2(1 / 1)$ & No & m.3460G $>A$ & $\mathrm{H} 40 \mathrm{a}$ \\
\hline 5 & L57 & $-/-$ & $1(1 / 0)$ & Yes & $\mathrm{m} .3460 \mathrm{G}>\mathrm{A}$ & V1a1 \\
\hline 6 & L58 & $-1-$ & $2(1 / 1)$ & Yes & m.3460G $>A$ & $\mathrm{~J} 1 \mathrm{c} 3$ \\
\hline 7 & L61 & $-/-$ & $4(2 / 2)$ & Yes & m.3460G $>A$ & $\mathrm{H} 1 \mathrm{~b} 1$ \\
\hline 8 & $\mathrm{~L} 30 * * *$ & $-/-$ & $19(11 / 8)$ & Yes & $\mathrm{m} .3635 \mathrm{G}>\mathrm{A}$ & $\mathrm{J} 2 \mathrm{~b} 1 \mathrm{c} 1$ \\
\hline 9 & $\mathrm{~L} 2 * *$ & $-/-$ & $6(2 / 4)$ & Yes & $\mathrm{m} \cdot 10663 \mathrm{~T}>\mathrm{C}$ & J1c4 \\
\hline 10 & $\mathrm{~L} 1 *$ & Russian & $9(1 / 8)$ & Yes & $\mathrm{m} .11778 \mathrm{G}>\mathrm{A}$ & $\mathrm{T} 2 \mathrm{~b}$ \\
\hline 11 & $\mathrm{~L} 3$ * & $-/-$ & $4(1 / 3)$ & Yes & m.11778G $>A$ & $\mathrm{~T} 2 \mathrm{~d} 1 \mathrm{~b} 1$ \\
\hline 12 & $\mathrm{~L} 5 *$ & $-/-$ & $1(1 / 0)$ & Yes & m.11778G $>A$ & $\mathrm{~J} 1 \mathrm{c} 2 \mathrm{i}$ \\
\hline 13 & $\mathrm{~L} 12 *$ & $-/-$ & $2(1 / 1)$ & No & m.11778G $>A$ & $\mathrm{~J} 2 \mathrm{~b} 1 \mathrm{a} 1$ \\
\hline 14 & L14* & $-/-$ & $5(2 / 3)$ & No & m.11778G $>A$ & $\mathrm{~T} 2 \mathrm{~b} 28$ \\
\hline
\end{tabular}


Table 1. Cont.

\begin{tabular}{|c|c|c|c|c|c|c|}
\hline No. & $\begin{array}{l}\text { Family } \\
\text { Name }\end{array}$ & $\begin{array}{l}\text { Ethnicity in } \\
\text { Maternal Line }\end{array}$ & $\begin{array}{c}\text { Number of } \\
\text { Examined } \\
\text { Individuals } \\
\text { (Affected/Healthy) }\end{array}$ & $\begin{array}{c}\text { Family } \\
\text { History of } \\
\text { Visual Loss }\end{array}$ & $\begin{array}{c}\text { Primary } \\
\text { LHON } \\
\text { Mutation } \\
\text { (MITOMAP) }\end{array}$ & $\begin{array}{c}\text { mtDNA } \\
\text { Haplogroup }\end{array}$ \\
\hline 15 & L23* & Azerbaijani & $1(1 / 0)$ & Unknown & m.11778G $>A$ & $\mathrm{~J} 2 \mathrm{~b} 1$ \\
\hline 16 & L26* & $-/-$ & $13(8 / 5)$ & Yes & m.11778G $>A$ & $\mathrm{~J} 1 \mathrm{c} 7 \mathrm{a}$ \\
\hline 17 & $\mathrm{~L} 27 * * *$ & $-/-$ & $11(2 / 9)$ & Yes & m.11778G $>A$ & $\mathrm{H} 2 \mathrm{a} 5 \mathrm{~b}$ \\
\hline 18 & $\mathrm{~L} 28 * * *$ & $-/-$ & $9(2 / 7)$ & Yes & m.11778G $>A$ & $\mathrm{~T} 2 \mathrm{~b} 8$ \\
\hline 19 & L38 & Ukrainian & $2(2 / 0)$ & Yes & m.11778G $>$ A & $\mathrm{J} 1 \mathrm{c} 2 \mathrm{c} 2 \mathrm{a}$ \\
\hline 20 & L39 & Unknown & $2(1 / 1)$ & No & m.11778G $>A$ & $\mathrm{~V}$ \\
\hline 21 & $\mathrm{~L} 42$ & Belarusian & $2(1 / 1)$ & Yes & m.11778G $>A$ & $\mathrm{H} 1 \mathrm{c}$ \\
\hline 22 & $\mathrm{~L} 43$ & Russian & $3(1 / 2)$ & No & m.11778G $>A$ & $\mathrm{H}$ \\
\hline 23 & L49 & Unknown & $1(1 / 0)$ & No & m.11778G $>A$ & $\mathrm{~K} 1 \mathrm{c}$ \\
\hline 24 & L52 & Russian & $3(1 / 2)$ & No & m.11778G $>A$ & $\mathrm{~J} 1 \mathrm{c} 2$ \\
\hline 25 & L53 & Unknown & $3(1 / 2)$ & Unknown & $\mathrm{m} .11778 \mathrm{G}>\mathrm{A}$ & H1b2 \\
\hline 26 & L60 & Russian & $2(1 / 1)$ & No & m.11778G $>A$ & $\mathrm{H} 1 \mathrm{~b} 2$ \\
\hline 27 & L10* & $-/-$ & $8(3 / 5)$ & Yes & $\mathrm{m} .14484 \mathrm{~T}>\mathrm{C}$ & M9a1a1c1a \\
\hline 28 & L17* & $-/-$ & $8(4 / 4)$ & Yes & $\mathrm{m} \cdot 14484 \mathrm{~T}>\mathrm{C}$ & $\mathrm{J} 1 \mathrm{c} 2 \mathrm{c} 1$ \\
\hline 29 & L32 & Unknown & $1(1 / 0)$ & Unknown & m.14484T $>C$ & $\mathrm{~V}$ \\
\hline 30 & L40 & Albanian & $1(1 / 0)$ & Yes & m.14484T $>C$ & $\mathrm{H}$ \\
\hline 31 & L47 & $-/-$ & $1(1 / 0)$ & $\mathrm{No}$ & $\mathrm{m} .14484 \mathrm{~T}>\mathrm{C}$ & J1c5a1 \\
\hline 32 & L50 & Unknown & $1(1 / 0)$ & Unknown & $\mathrm{m} \cdot 14484 \mathrm{~T}>\mathrm{C}$ & U5a2b1c \\
\hline 33 & L6 & $-/-$ & $2(2 / 0)$ & No & - & U4a1d \\
\hline 34 & L8 & Unknown & $1(1 / 0)$ & No & - & U2e1 \\
\hline 35 & L9 & Russian & $2(2 / 0)$ & Yes & - & U5a1b1c1 \\
\hline 36 & L20 & $-/-$ & $3(2 / 1)$ & Yes & - & $\mathrm{U} 4 \mathrm{~b} 1 \mathrm{~b} 1$ \\
\hline 37 & $\mathrm{~L} 31 * * *$ & $-/-$ & $3(2 \backslash 1)$ & Yes & - & U3b1b \\
\hline 38 & $\mathrm{~L} 45$ & $-/-$ & $2(1 / 1)$ & $\mathrm{No}$ & - & U5a2e \\
\hline 39 & L46 & $-/-$ & $2(1 / 1)$ & No & - & H13a1d \\
\hline 40 & L51 & Unknown & $1(1 / 0)$ & Unknown & - & $\mathrm{U} 2 \mathrm{c} 1 \mathrm{~b}$ \\
\hline 41 & L54 & Russian & $2(1 / 1)$ & No & - & $\mathrm{U} 4 \mathrm{a} 2 \mathrm{a}$ \\
\hline 42 & L56 & $-/-$ & $2(1 / 1)$ & No & - & $\mathrm{J} 1 \mathrm{c} 1 \mathrm{~b} 1$ \\
\hline 43 & L59 & Ukrainian & $2(1 / 1)$ & No & - & $\mathrm{V7a}$ \\
\hline 44 & L62 & $-/-$ & $1(1 / 0)$ & Yes & - & $\mathrm{H}$ \\
\hline
\end{tabular}

According to the family pedigrees, only $50 \%$ (22/44) of cases had a family history of vision loss in the maternal lineage in more than one generation, among which $\mathrm{m} .11778 \mathrm{G}>\mathrm{A}$ represented $36 \%(8 / 22)$, m.3460G $>$ A covered 23\% (5/22), and the $\mathrm{m} .14484 \mathrm{~T}>\mathrm{C}$ was $14 \%(3 / 22)$, as well as those without primary mutations (LHON-like cases), which represented 18\% (4/22). Rare mutation cases (m.10663T $>C$ and m.3635G $>$ A) were family-inherited. In total, 39\% (17/44) of cases were sporadic, among which 13 were cases with only one affected person diagnosed, and four were cases with two affected persons in one generation. Among the sporadic cases, m.11778G $>$ A represented $41 \%(7 / 17), \mathrm{m} .3460 \mathrm{G}>\mathrm{A}$ was $12 \%$ (2/17), m.14484T>C was 6\% (1/17), and the LHON-like cases represented $41 \%(7 / 17)$ of the total. 
Summary information on penetrance is shown in Table 2. The penetrance is highly variable between separate families, even with the same primary mutation. The average penetrance among men was $32 \%(6-100 \%)$ and $12 \%$ among women $(0-58 \%)$; these correlate with data previously published [4]. However, there are some families with higher penetrance among females than among males: L24, L26, and L28.

Table 2. Summary information about penetrance.

\begin{tabular}{ccccc}
\hline & m.11778G $>$ A $(n=15)$ & m.14484T $>$ C $(n=4)$ & m.3460G $>$ A $(n=7)$ & Average \\
\hline Males & $34 \%$ & $46 \%$ & $15 \%$ & $32 \%$ \\
\hline Females & $12 \%$ & $12 \%$ & $10 \%$ & $12 \%$ \\
\hline
\end{tabular}

In 12 families with clear-cut LHON phenotypes, no pathogenic mtDNA mutations were found. Analysis of the mtDNA revealed non-synonymous mutations: m.4766A>G, m.13105A $>G, m .14002 A>G$, which have not been noted as associated with LHON or other diseases in the MITOMAP database. All pathogenicity prediction tools indicated low probability that the amino acid substitutions are disease-associated for these mutations. Mutation m.4659G $>$ A has been previously reported as being associated with Parkinson's disease [35], as well as in an Australian LHON pedigree that was heteroplasmic for the m.14484T >C [36]. Polyphen-2 predicted the pathogenicity for this mutation as benign and MutPed 2 showed low probability score, but MutPred 1.2, PROVEAN, and SIFT determined this mutation as deleterious. The results are shown in Table 3.

Table 3. Non-synonymous mutations revealed in LHON-like cases. Known primary mutations (m.3460G $>$ A, m.3635G $>$, m.10663T $>C, m .11778 G>A$, and m.14484T $>$ C) are placed in bold to demonstrate distinction between different prediction algorithms and frequencies in general population for pathogenic mutations. A MutPred 1.2 score $>0.75$ and a Mutpred 2 score $>0.50$ would suggest pathogenicity.

\begin{tabular}{|c|c|c|c|c|c|c|c|c|}
\hline Mutation & $\begin{array}{l}\text { Protein-Coding } \\
\text { Region of } \\
\text { mtDNA }\end{array}$ & $\begin{array}{l}\text { Amino Acid } \\
\text { Substitution }\end{array}$ & $\begin{array}{l}\text { PolyPhen } \\
-2 \text { Score }\end{array}$ & $\begin{array}{c}\text { MutPred } \\
1.2 / 2 \\
\text { Score } \\
\text { (Cutoff } \\
0.75 / 0.50 \text { ) } \\
\end{array}$ & $\begin{array}{c}\text { PROVEAN/SIFT } \\
\text { Pathogenicity } \\
\text { Prediction }\end{array}$ & $\begin{array}{c}\text { Frequency } \\
\text { in General } \\
\text { Population } \\
\text { (as per } \\
\text { mtDB) }\end{array}$ & $\begin{array}{c}\text { Frequency } \\
\text { in General } \\
\text { Population } \\
\text { (as per } \\
\text { HmtDB) }\end{array}$ & Family \\
\hline m.14002A>G & ND5 & T556A & $\begin{array}{c}0.002 \\
\text { (benign) }\end{array}$ & $0.387 / 0.059$ & $\begin{array}{l}\text { Neutral/ } \\
\text { Tolerated }\end{array}$ & 0.0037 & 0.00289 & L45 \\
\hline $\mathrm{m} .4766 \mathrm{~A}>\mathrm{G}$ & ND2 & M99I & $\begin{array}{c}0.001 \\
\text { (benign) }\end{array}$ & $0.571 / 0.225$ & $\begin{array}{c}\text { Neutral/ } \\
\text { Tolerated }\end{array}$ & 0 & 0.00009 & L46 \\
\hline m. $4659 \mathrm{G}>\mathrm{A}$ & ND2 & A64T & $\begin{array}{c}0.029 \\
\text { (benign) }\end{array}$ & $0.790 / 0.256$ & $\begin{array}{l}\text { Deleterious/ } \\
\text { Damaging }\end{array}$ & 0.0011 & 0.00161 & \multirow{2}{*}{ L51 } \\
\hline m.13105A>G & ND5 & I257V & $\begin{array}{c}0.001 \\
\text { (benign) }\end{array}$ & $0.198 / 0.032$ & $\begin{array}{c}\text { Neutral/ } \\
\text { Tolerated }\end{array}$ & 0.0612 & 0 & \\
\hline $\mathrm{m} .3460 \mathrm{G}>\mathrm{A}$ & ND1 & $\mathrm{A} 52 \mathrm{~T}$ & $\begin{array}{c}1.000 \\
\text { (probably } \\
\text { damaging) }\end{array}$ & $0.789 / 0.418$ & $\begin{array}{c}\text { Neutral/ } \\
\text { Damaging }\end{array}$ & 0.0097 & 0.00058 & - \\
\hline m.3635G >A & ND1 & S110N & $\begin{array}{c}0.999 \\
\text { (probably } \\
\text { damaging) }\end{array}$ & $0.873 / 0.493$ & $\begin{array}{l}\text { Deleterious/ } \\
\text { Damaging }\end{array}$ & 0 & 0.00027 & - \\
\hline m.10663T $>C$ & ND4L & V65A & $\begin{array}{c}0.946 \\
\text { (probably } \\
\text { damaging) }\end{array}$ & $0.604 / 0.694$ & $\begin{array}{l}\text { Deleterious/ } \\
\text { Damaging }\end{array}$ & 0 & 0.00003 & - \\
\hline m.11778G >A & ND4 & $\mathrm{R} 340 \mathrm{H}$ & $\begin{array}{c}0.999 \\
\text { (probably } \\
\text { damaging) }\end{array}$ & $0.919 / 0.494$ & $\begin{array}{c}\text { Deleterious/ } \\
\text { Damaging }\end{array}$ & 0.0097 & 0.0034 & - \\
\hline m.14484T $>C$ & ND6 & M64V & $\begin{array}{c}0.993 \\
\text { (probably } \\
\text { damaging) }\end{array}$ & $0.618 / 0.787$ & $\begin{array}{c}\text { Neutral/ } \\
\text { Damaging }\end{array}$ & 0.0026 & 0.00146 & - \\
\hline
\end{tabular}

In several families with primary mutations (L01, L03, L12, L28, L30, L40, L43, and L50) we found out additional, non-synonymous mutations (Table 4). Mutations m.8875T $>$ C, m.14582A $>$ G, 
m.8400T $>C$, and m.4639T $>C$ were neutral, and mutation m.9444C $>\mathrm{T}$ had a high probability of being pathogenic, according to data from all the pathogenicity prediction tools; for other mutations, we observed divergence of prediction results. Since prediction results for primary pathogenic mutations diverged too (see Table 3), novel non-synonymous nucleotide change was considered potentially pathogenic if it had extremely low frequency in the general population, and if it was predicted by at least three algorithms to have an effect on protein function. For mutations m.6261G $>A$ and m.15468C $>$ T, only PolyPhen 2 predicted pathogenicity as probably damaging and possible damaging, respectively. However, mutation $\mathrm{m} .6261 \mathrm{G}>\mathrm{A}$ had already been reported by Abu-Amero [37] in patients with optic neuropathy, and also as a somatic mutation associated with prostate cancer. Interestingly, the family (L01) with m.6261G $>\mathrm{A}$ and $\mathrm{m} .11778 \mathrm{G}>\mathrm{A}$ has the same haplogroup, $\mathrm{T} 2$, as the case reported by Abu-Amero. Other mutations (m.8412T $>$ C, m.8551T $>$ C, m.9921G $>$ A, m.15077G $>$ A) were predicted as pathogenic by at least by three algorithms, but the first three of them have not been noted as associated with diseases in the MITOMAP database, and mutation m.15077G $>$ A was reported as being associated with maternally-inherited isolated deafness [38].

Table 4. Additional, non-synonymous mutations revealed in LHON cases. All these mutations still have no the status of "primary LHON mutations". A MutPred 1.2 score $>0.75$ and a Mutpred 2 score > 0.50 would suggest pathogenicity.

\begin{tabular}{|c|c|c|c|c|c|c|c|c|}
\hline Mutation & $\begin{array}{l}\text { Protein-Coding } \\
\text { Region of } \\
\text { mtDNA }\end{array}$ & $\begin{array}{l}\text { Amino Acid } \\
\text { Substitution }\end{array}$ & $\begin{array}{l}\text { PolyPhen-2 } \\
\text { Score }\end{array}$ & $\begin{array}{c}\text { MutPred } \\
1.2 / 2 \\
\text { Score } \\
\text { (Cutoff } \\
0,75 / 0,50)\end{array}$ & $\begin{array}{c}\text { PROVEAN } \\
\text { /SIFT } \\
\text { Prediction }\end{array}$ & $\begin{array}{c}\text { Frequency } \\
\text { in General } \\
\text { Population } \\
\text { (mtDB) }\end{array}$ & $\begin{array}{c}\text { Frequency } \\
\text { in General } \\
\text { Population } \\
\text { (HmtDB) }\end{array}$ & Family \\
\hline m.6261G >A & $\mathrm{CO} 1$ & $\mathrm{~A} 120 \mathrm{~T}$ & $\begin{array}{c}0.998 \\
\text { (probably } \\
\text { damaging) }\end{array}$ & $0.491 / 0.324$ & $\begin{array}{c}\text { Neutral/ } \\
\text { Tolerated }\end{array}$ & 0.0048 & 0.00553 & L01 \\
\hline $\mathrm{m} .8875 \mathrm{~T}>\mathrm{C}$ & ATP6 & F117L & 0 (benign) & $0.251 / 0.429$ & $\begin{array}{c}\text { Neutral/ } \\
\text { Tolerated }\end{array}$ & 0.0007 & 0.001276 & L03 \\
\hline m.9921G >A & $\mathrm{CO} 3$ & A239T & $\begin{array}{c}0.009 \\
\text { (benign) }\end{array}$ & $0.543 / 0.624$ & $\begin{array}{l}\text { Deleterious/ } \\
\text { Damaging }\end{array}$ & 0.0011 & 0.00082 & L12 \\
\hline m.15468C > T & СYB & $\mathrm{T} 241 \mathrm{M}$ & $\begin{array}{c}0.890 \\
\text { (possible } \\
\text { damaging) }\end{array}$ & $0.245 / 0.079$ & $\begin{array}{l}\text { Neutral/ } \\
\text { Tolerated }\end{array}$ & 0.0004 & 0.00043 & L28 \\
\hline $\mathrm{m} .8551 \mathrm{~T}>\mathrm{C}$ & ATP6 & F9L & $\begin{array}{c}0.976 \\
\text { (probably } \\
\text { damaging) }\end{array}$ & $0.676 / 0.418$ & $\begin{array}{l}\text { Deleterious/ } \\
\text { Damaging }\end{array}$ & 0.0007 & 0 & L30 \\
\hline m. $14582 A>G$ & ND6 & V31A & $\begin{array}{c}0.003 \\
\text { (benign) }\end{array}$ & $0.245 / 0.181$ & $\begin{array}{l}\text { Neutral/ } \\
\text { Tolerated }\end{array}$ & 0.0086 & 0.00571 & L40 \\
\hline $\mathrm{m} .8400 \mathrm{~T}>\mathrm{C}$ & ATP8 & M12T & 0 (benign) & $0.504 / 0.118$ & $\begin{array}{l}\text { Neutral/ } \\
\text { Tolerated }\end{array}$ & 0.0011 & 0.00052 & \multirow[b]{2}{*}{ L43 } \\
\hline $\mathrm{m} .9444 \mathrm{C}>\mathrm{T}$ & $\mathrm{CO} 3$ & R80W & $\begin{array}{c}0.999 \\
\text { (probably } \\
\text { damaging) }\end{array}$ & $0.875 / 0.586$ & $\begin{array}{l}\text { Deleterious/ } \\
\text { Damaging }\end{array}$ & 0 & 0 & \\
\hline $\mathrm{m} .4639 \mathrm{~T}>\mathrm{C}$ & ND2 & I57T & $\begin{array}{c}0.001 \\
\text { (benign) }\end{array}$ & $0.297 / 0.047$ & $\begin{array}{c}\text { Neutral/ } \\
\text { Tolerated }\end{array}$ & 0.0082 & 0.00395 & \multirow{3}{*}{ L50 } \\
\hline $\mathrm{m} .8412 \mathrm{~T}>\mathrm{C}$ & ATP8 & M16T & $\begin{array}{c}0.711 \\
\text { (possible } \\
\text { damaging) }\end{array}$ & $0.677 / 0.542$ & $\begin{array}{c}\text { Deleterious/ } \\
\text { Tolerated }\end{array}$ & 0 & 0.00039 & \\
\hline m.15077G $>$ A & CYB & E111K & $\begin{array}{c}0.992 \\
\text { (probably } \\
\text { damaging) }\end{array}$ & $0.684 / 0.331$ & $\begin{array}{c}\text { Deleterious/ } \\
\text { Damaging (low } \\
\text { confidence) }\end{array}$ & 0.0007 & 0.00213 & \\
\hline
\end{tabular}

Phylogenetic analysis illustrates that Siberian carriers of pathogenic LHON mutations are unrelated and belong to different maternal lines. In rare cases (4/44), m.3460G $>A$ and $\mathrm{m} .14484 \mathrm{~T}>\mathrm{C}$ belong to East Eurasian M8, M9, and D haploclusters (Figure 1). The classic (m.3460G >A, m.11778G $>$ A, m.14484T $>$ C) and rare LHON-causing mutations occur mostly in the mtDNA background of West Eurasian haploclusters $\mathrm{H}^{\prime} \mathrm{V}$ (Figure 2), J'T and U'K (Figure 3). 


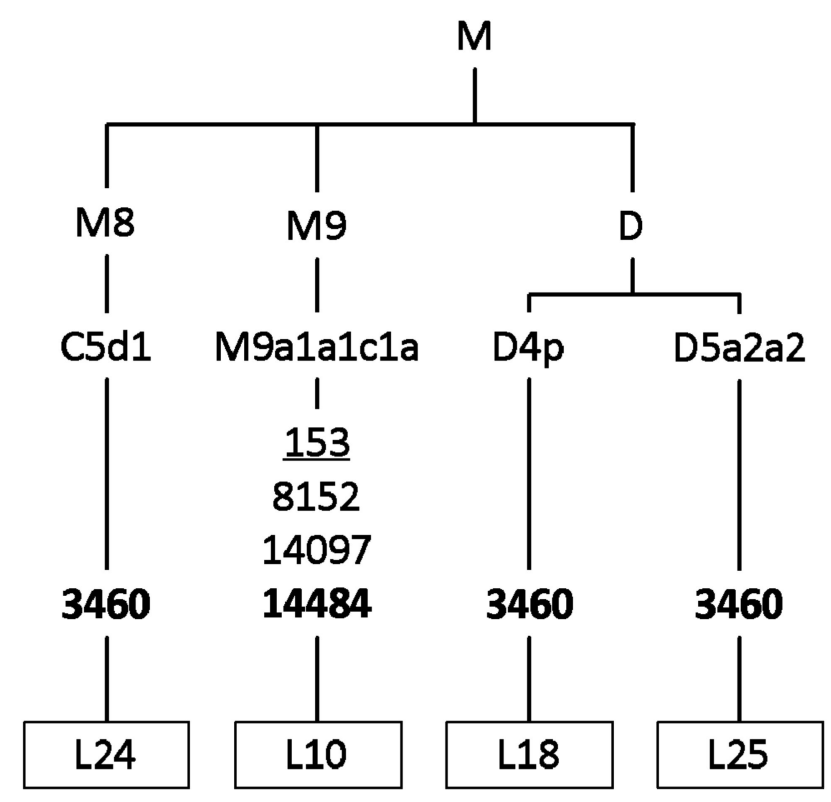

Figure 1. Phylogenetic tree based on the complete mtDNA genome sequences of pedigree probands with pathogenic LHON mutations (M8, M9, and D haploclusters). The non-synonymous coding region variants are denoted by "ns" (known pathogenic mutations designated in bold). Mutations are transitions unless a specific base change was specified; deletions are denoted by "del"; underlined mutations are recurrent.

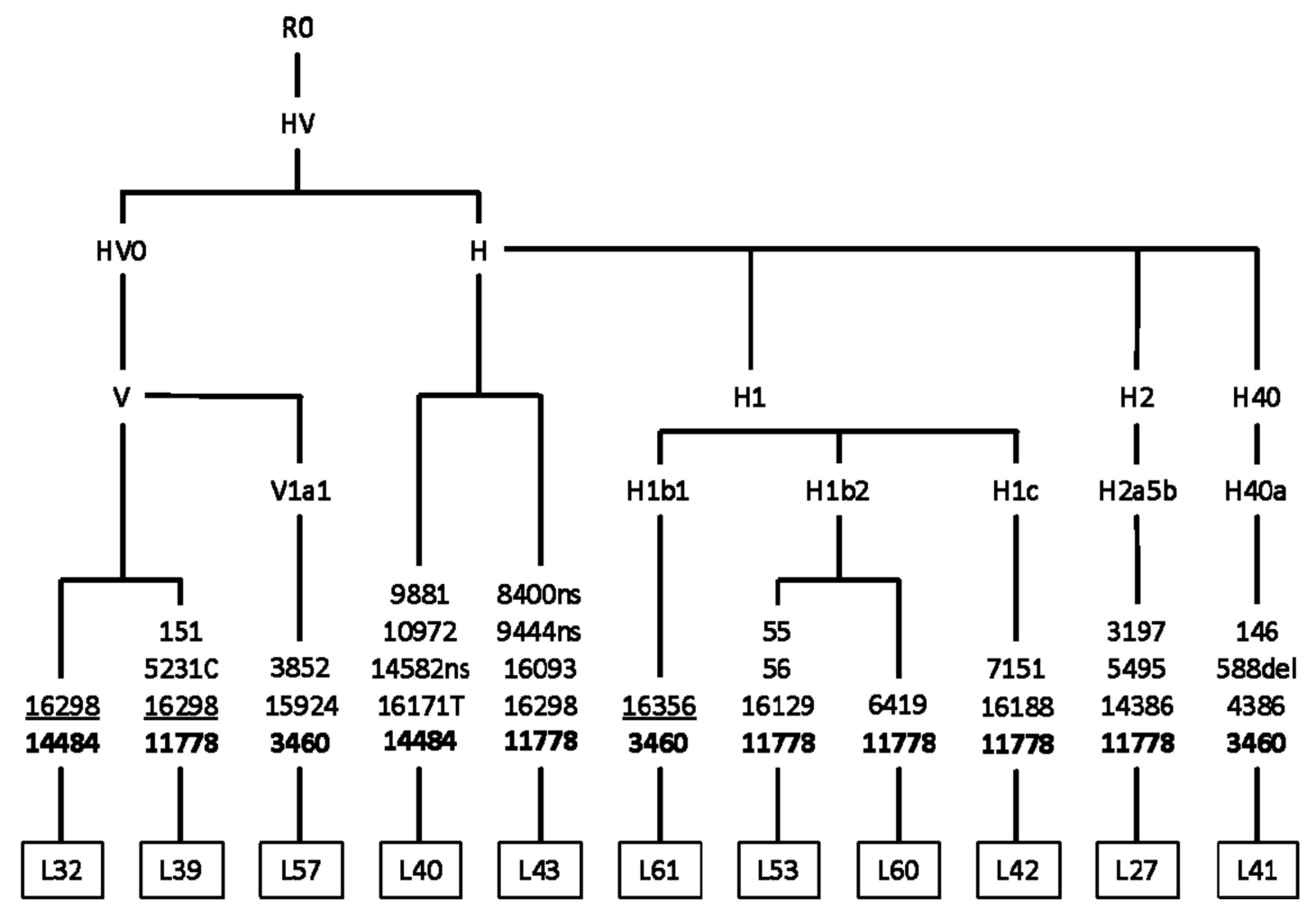

Figure 2. Phylogenetic tree based on the complete mtDNA genome sequences of pedigree probands with pathogenic LHON mutations ( $\mathrm{H}^{\prime} \mathrm{V}$ haplocluster). The non-synonymous coding region variants are denoted by "ns" (known pathogenic mutations designated in bold). Mutations are transitions unless a specific base change was specified; deletions are denoted by "del"; underlined mutations are recurrent. 


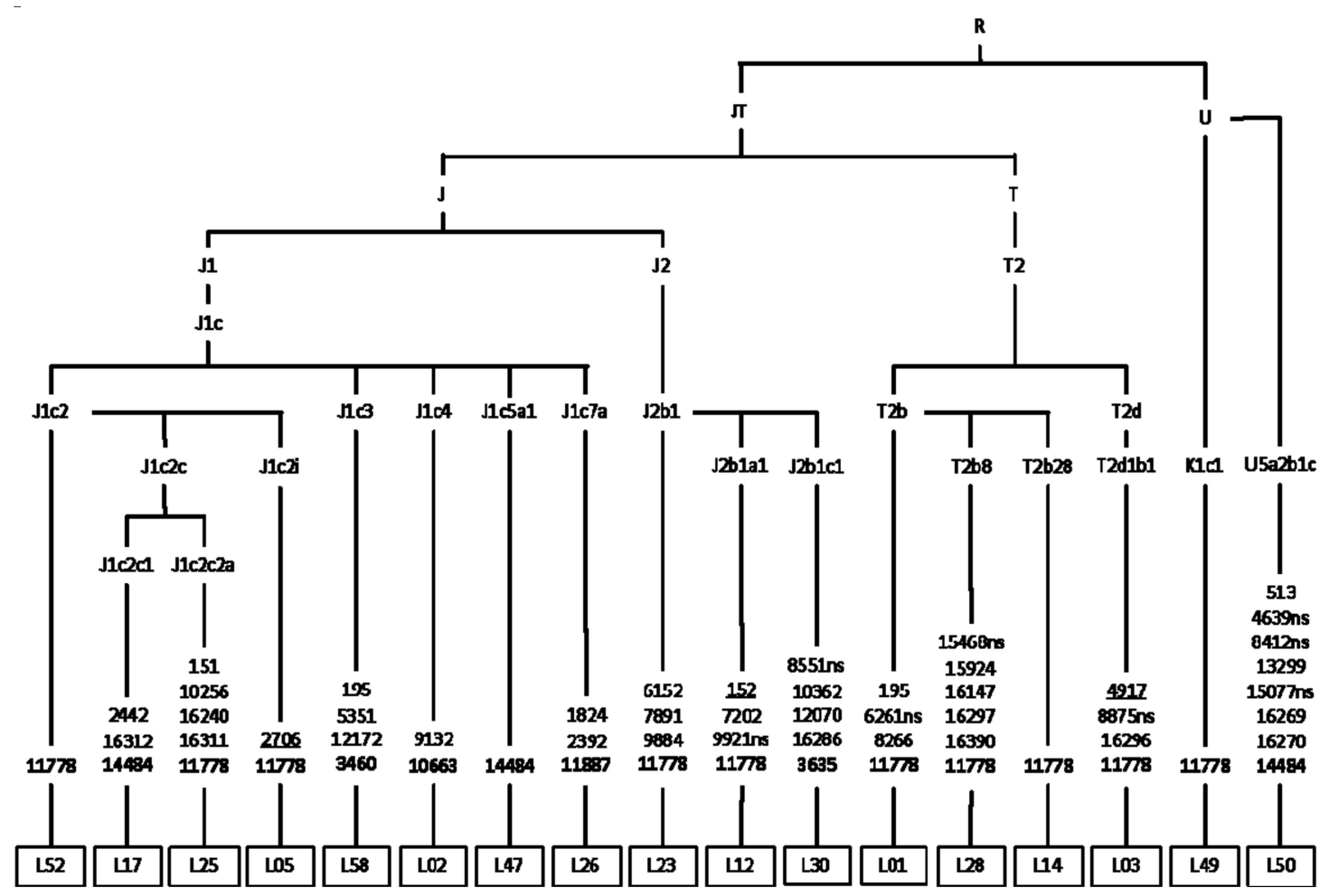

Figure 3. Phylogenetic tree based on the complete mtDNA genome sequences of pedigree probands with pathogenic LHON mutations (J'T, and U'K haploclusters). The non-synonymous coding region variants are denoted by "ns" (known pathogenic mutations designated in bold). Mutations are transitions unless a specific base change was specified; deletions are denoted by "del"; underlined mutations are recurrent.

\section{Discussion}

\subsection{Leber's Hereditary Optic Neuropathy Primary Mutations}

Regarding our preliminary data, the frequencies of primary mutations are different from frequencies reported for Europe and Asia. The most prevalent m.11778G $>$ A ( 55\%) is less common in Western Siberia than in Europe, at $69 \%$ [9]; as well as in China and Japan, at $90 \%[10,13]$. The prevalence of m.3460G $>\mathrm{A}(\sim 24 \%)$ is twice as much as in Europe, but m.14484T $>\mathrm{C}(\sim 14 \%)$ do not deviate from those of other European populations [9].

In 12 families with LHON-like manifestation, no known pathogenic mtDNA mutation was found. However, there are other elaborations in which the clinical diagnosis cannot be confirmed by molecular genetic analysis [37,39-41]. Definitively, mtDNA mutation-caused LHON is clinically indistinguishable from the other forms of optic neuropathy, such as a dominant optic neuropathy (DOA), especially when it is sporadic. Compared to LHON, DOA visual loss is detected between ages 4 and 6 in the majority of patients, and $58-84 \%$ of patients with DOA report visual impairment by age 11 [42]. In our 12 cases, the ages of onset were between 13-36 years. We will be studying these cases for the mutation spectrum of common pathogenic genes for DOA in future.

\subsection{Penetrance}

We suppose that relatively reduced incidence of LHON in Western Siberia is associated with incomplete penetrance and diagnostic difficulties of atypical (e.g., late-onset) and combined (e.g., multiple sclerosis) forms of LHON. Patients with LHON could have also been wrongly diagnosed as suffering from toxic amblyopia, tobacco-alcohol amblyopia, or optic neuritis [41]. On the other hand, the problem is that patients do not know their family history. Molecular testing for LHON 
is not routinely performed in patients with optic atrophy in Russian Federation. Identification and registration of unaffected carriers plays an important role for prevention of disease manifestation. For example, there is strong evidence that smoking is associated with an increased risk of visual failure among LHON carriers-93\% penetrance of vision loss in male smokers versus $66 \%$ in male non-smokers [17].

Our observations highlight the importance of molecular genetic examination for unaffected carriers. The presence of pathogenic mutations should be tested not only for probands, but for all relatives in the maternal line, Since the proportion of sporadic cases is about $40 \%$ according to our published data [4].

\subsection{Potentially Pathogenic Mutation m.4659G>A}

We found $\mathrm{m} .4659 \mathrm{G}>\mathrm{A}$ in one subject without any known primary mutations (L51). This sequence change is located at codon 64 in the functional domain of the ND2 gene and changes an alanine-a hydrophobic amino acid—into threonine-a neutral amino acid. Mutation m.4659G $>$ A has been reported as being associated with LHON in an Australian pedigree that also had heteroplasmic mutations m.14484T $>$ C and m.5460G $>$ A [36]. This family had 10 maternally-related descendants, five of whom had vision loss. Unfortunately, our patient does not know his family history, and we could not confirm maternal inheritance for this mutation. However, m.4659G $>$ A has very low frequency in the general population (0.0011-0.00161), and has a high probability of being pathogenic (Table 3).

\subsection{Additional Non-Synonymous Mutations Revealed in LHON Cases}

The phenomenon of co-existence of two pathogenic mutations in one family has already been described. The first case included m.4659G $>$ A, m.5460G $>$ A, and m.14484T $>C$ in an Australian LHON pedigree, described above [36]. In the second case, a Polish family harboring two primary LHON mutations m.3460G $>$ A and m.11778G $>$ A occurred in a haplogroup H background [43]. In the third case, a family harbored two primary LHON mutations, m.11778G $>$ A and m.14484T $>C$, and both mutations had a synergistic pathogenic effect on protein function, as well as a higher degree of heteroplasmy of the m.14484T $>C$, correlated with an earlier age at onset [44]. Finally, the fourth example is a unique double-mutant ND4L with two concurrent mutations (m.10609T $>C$ and m.10663T $>C$ ) in an Arab pedigree from Kuwait [45].

We reported mutations m.6261G $>$ A, m.8412T $>$ C, m.8551T $>$ C, m.9444C $>$ T, m.9921G $>$ A, and $\mathrm{m} .15077 \mathrm{G}>\mathrm{A}$, which could be potentially pathogenic because of their low frequency in the general population, and high probability of pathogenicity according to data from different prediction tools. Two of them, m.6261G $>$ A and m.15077G $>$ A, have already been reported in subjects with optic neuropathy and maternally-inherited isolated deafness, respectively. However, we suppose that additional non-synonymous mutations could either have a synergistically pathogenic or a protective effect. To demonstrate the full significance of novel mutations, a respiratory chain assay would need to be performed. An example is the study [38], where cybrids with m.15077G $>$ A showed normal activities for mitochondrial electron chain enzymatic complexes.

\subsection{Haplogroup Analysis}

Our LHON cohort from the Western Siberia region is represented predominantly by West Eurasian haplogroups and includes several East Eurasian haplogroups, namely C5d1 (L24), D4p (L18), D5a2a2 (L25), and M9a1a1c1a (L10).

Rare LHON mutations m.10663T $>C$ and $\mathrm{m} .3635 \mathrm{G}>\mathrm{A}$ were found in Russian families from Kazakhstan (the first) and the Novosibirsk region (the second), associated with the European haplogroups J1c4 and J2b1c1, respectively [21,22]. Mutation m.10663T>C was also reported in the background of the haplogroups J1c2c, L2a1, L3'4, and L3f1b [37,45-47], and mutation m.3635G>A was reported in haplogroups R11a, D4g2b, M7b4, F1a, B5b, and M7b [48,49]. The presence of the 
same pathogenic mutations on the background of various mitochondrial haplogroups confirms that pathogenic LHON mutations arise de novo, independently from the mtDNA or ethnic backgrounds.

It is known that the clinical impact of mDNA mutations may be modulated by mitochondrial haplogroup background. For example, Hudson et al. performed a multicenter study of 3613 subjects from 159 different families, and showed that the risk of visual failure is greater when $\mathrm{m} \cdot 11778 \mathrm{G}>\mathrm{A}$ or m.14484T $>C$ mutations are present in specific subgroups of haplogroup J; the same as the m.3460G $>A$ mutation is present in haplogroup $\mathrm{K}$, and the risk of visual failure is significantly lower when m.11778G $>$ A occurs in haplogroup H [50]. Romero et al. supposed that haplogroup D has a protective effect in carriers of LHON mutations. His hypothesis was based on the fact that there was a markedly decreased frequency of haplogroup D in Chilean subjects with LHON, as haplogroup D is one of the most common in the Chilean population [12]. Also, other experimental research serves as proof that cybrids and fibroblasts bearing LHON mutations have different response to neurotoxic agents, depending on haplogroup background [51].

It has been suggested that at the end of the last glaciation, phylogenetically more ancient mutations could have provided their carriers with adaptive advantages during the human population expansion. Today, those mutations contribute to the saving and expression of weakly pathogenic LHON mutations, which appear randomly in different region-specific genetic backgrounds [52,53]. The theory could be tested by further searching of pathogenic, LHON-causing mutations in relation to specific mtDNA backgrounds (phylogenetically ancient set of mutations).

New data collected from future studies regarding mtDNA variations of LHON in Western Siberia might be used to develop a LHON system registry in the Russian Federation. We intend to conduct consecutive experimental research, including the parameters of the pathogenicity of each novel substitution.

\section{Limitations of the Study}

The main limitation of the data presented is the absence of physiological tests as proof with respect to the pathogenicity of novel mtDNA substitutions. Additional tests should be done, such as oxygen consumption, ATP and ROS measuring, and electron microscopy study (for example, [54]). In addition, development of the newest editing systems [55] could give us more reliable instruments to test pathogenicity.

Author Contributions: Conceptualization, E.S. and R.S.; data curation, I.B., E.S., S.S., S.D., A.N., N.V., I.M., and R.S.; analysis and interpretation of data, E.S., S.S., S.D., A.N., and R.S., writing-review and editing, E.S., S.S., S.D., A.N., I.M., and R.S.

Funding: The research was supported by the Russian Science Foundation [No. 17-75-20015] and the Russian Foundation of Basic Research [No. 19-29-04101].

Conflicts of Interest: The authors declare no conflict of interest.

\section{References}

1. Baracca, A.; Solaini, G.; Sgarbi, G.; Lenaz, G.; Baruzzi, A.; Schapira, A.H.; Martinuzzi, A.; Carelli, V. Severe impairment of complex I-driven adenosine triphosphate synthesis in leber hereditary optic neuropathy cybrids. Arch. Neurol. 2005, 62, 730-736. [CrossRef] [PubMed]

2. Lin, C.S.; Sharpley, M.S.; Fan, W.; Waymire, K.G.; Sadun, A.A.; Carelli, V.; Ross-Cisneros, F.N.; Baciu, P.; Sung, E.; McManus, M.J.; et al. Mouse mtDNA mutant model of Leber hereditary optic neuropathy. Proc Natl. Acad. Sci. USA 2012, 109, 20065-20070. [CrossRef] [PubMed]

3. Kim, U.S.; Jurkute, N.; Yu-Wai-Man, P. Leber Hereditary Optic Neuropathy-Light at the End of the Tunnel? Asia Pac. J. Opthalmol. (Phila) 2018, 7, 242-245. [CrossRef]

4. Meyerson, C.; Van Stavern, G.; McClelland, C. Leber hereditary optic neuropathy: Current perspectives. Clin. Ophthalmol. 2015, 9, 1165-1176. [CrossRef] [PubMed] 
5. Majander, A.; Bowman, R.; Poulton, J.; Antcliff, R.J.; Reddy, M.A.; Michaelides, M.; Webster, A.R.; Chinnery, P.F.; Votruba, M.; Moore, A.T.; et al. Childhood-onset Leber hereditary optic neuropathy. Br. J. Ophthalmol. 2017, 101, 1505-1509. [CrossRef]

6. Finsterer, J.; Zarrouk-Mahjoub, S. Leber's hereditary optic neuropathy is multiorgan not mono-organ. Clin. Ophthalmol. 2016, 10, 2187-2190. [CrossRef]

7. Haas, R.H. Mitochondrial Dysfunction in Aging and Diseases of Aging. Biology 2019, 8, 48. [CrossRef]

8. Barcelos, I.P.d.; Troxell, R.M.; Graves, J.S. Mitochondrial dysfunction and multiple sclerosis. Biology 2019, 8, 37. [CrossRef]

9. Mackey, D.A.; Oostra, R.J.; Rosenberg, T.; Nikoskelainen, E.; Bronte-Stewart, J.; Poulton, J.; Harding, A.E.; Govan, G.; Bolhuis, P.A.; Norby, S. Primary pathogenic mtDNA mutations in multigeneration pedigrees with Leber hereditary optic neuropathy. Am. J. Hum. Genet. 1996, 59, 481-485.

10. Mashima, Y.; Yamada, K.; Wakakura, M.; Kigasawa, K.; Kudoh, J.; Shimizu, N.; Oguchi, Y. Spectrum of pathogenic mitochondrial DNA mutations and clinical features in Japanese families with Leber's hereditary optic neuropathy. Curr. Eye Res. 1998, 17, 403-408. [CrossRef]

11. Kumar, M.; Kaur, P.; Kumar, M.; Saxena, R.; Sharma, P.; Dada, R. Clinical characterization and mitochondrial DNA sequence variations in Leber hereditary optic neuropathy. Mol. Vis. 2012, 18, 2687-2699. [PubMed]

12. Romero, P.; Fernandez, V.; Slabaugh, M.; Seleme, N.; Reyes, N.; Gallardo, P.; Herrera, L.; Pena, L.; Pezo, P.; Moraga, M. Pan-American mDNA haplogroups in Chilean patients with Leber's hereditary optic neuropathy. Mol. Vis. 2014, 20, 334-340. [PubMed]

13. Jiang, P.; Liang, M.; Zhang, J.; Gao, Y.; He, Z.; Yu, H.; Zhao, F.; Ji, Y.; Liu, X.; Zhang, M.; et al. Prevalence of Mitochondrial ND4 Mutations in 1281 Han Chinese Subjects With Leber's Hereditary Optic Neuropathy. Invest Ophthalmol. Vis. Sci. 2015, 56, 4778-4788. [CrossRef] [PubMed]

14. Khan, N.A.; Govindaraj, P.; Soumittra, N.; Sharma, S.; Srilekha, S.; Ambika, S.; Vanniarajan, A.; Meena, A.K.; Uppin, M.S.; Sundaram, C.; et al. Leber's hereditary optic neuropathy-specific mutation m.11778G>A exists on diverse mitochondrial haplogroups in India. Invest. Ophthalmol. Vis. Sci. 2017, 58, 3923-3930. [CrossRef] [PubMed]

15. Laberge, A.M.; Jomphe, M.; Houde, L.; Vezina, H.; Tremblay, M.; Desjardins, B.; Labuda, D.; St-Hilaire, M.; Macmillan, C.; Shoubridge, E.A.; et al. A "Fille du Roy" introduced the T14484C Leber hereditary optic neuropathy mutation in French Canadians. Am. J. Hum. Genet. 2005, 77, 313-317. [CrossRef] [PubMed]

16. Jacobi, F.K.; Leo-Kottler, B.; Mittelviefhaus, K.; Zrenner, E.; Meyer, J.; Pusch, C.M.; Wissinger, B. Segregation patterns and heteroplasmy prevalence in Leber's hereditary optic neuropathy. Inves.t Ophthalmol. Vis. Sci. 2001, 42, 1208-1214.

17. Kirkman, M.A.; Yu-Wai-Man, P.; Korsten, A.; Leonhardt, M.; Dimitriadis, K.; De Coo, I.F.; Klopstock, T.; Chinnery, P.F. Gene-environment interactions in Leber hereditary optic neuropathy. Brain 2009, 132, 2317-2326. [CrossRef]

18. Istikharah, R.; Tun, A.W.; Kaewsutthi, S.; Aryal, P.; Kunhapan, B.; Katanyoo, W.; Chuenkongkaew, W.; Lertrit, P. Identification of the variants in PARL, the nuclear modifier gene, responsible for the expression of LHON patients in Thailand. Exp. Eye Res. 2013, 116, 55-57. [CrossRef]

19. Puomila, A.; Hamalainen, P.; Kivioja, S.; Savontaus, M.L.; Koivumaki, S.; Huoponen, K.; Nikoskelainen, E. Epidemiology and penetrance of Leber hereditary optic neuropathy in Finland. Eur. J. Hum. Genet. 2007, 15, 1079-1089. [CrossRef]

20. Mascialino, B.; Leinonen, M.; Meier, T. Meta-analysis of the prevalence of Leber hereditary optic neuropathy mtDNA mutations in Europe. Eur. J. Ophthalmol. 2012, 22, 461-465. [CrossRef]

21. Brown, M.D.; Zhadanov, S.; Allen, J.C.; Hosseini, S.; Newman, N.J.; Atamonov, V.V.; Mikhailovskaya, I.E.; Sukernik, R.I.; Wallace, D.C. Novel mtDNA mutations and oxidative phosphorylation dysfunction in Russian LHON families. Hum. Genet. 2001, 109, 33-39. [CrossRef] [PubMed]

22. Brown, M.D.; Starikovskaya, E.; Derbeneva, O.; Hosseini, S.; Allen, J.C.; Mikhailovskaya, I.E.; Sukernik, R.I.; Wallace, D.C. The role of mtDNA background in disease expression: A new primary LHON mutation associated with Western Eurasian haplogroup. J. Hum. Genet. 2002, 110, 130-138. [CrossRef] [PubMed]

23. Volod'ko, N.V.; L’Vova, M.; Starikovskaia, E.B.; Derbeneva, O.A.; Bychkov, I.; Mikhailovskaia, I.E.; Pogozheva, I.V.; Fedotov, F.F.; Soyan, G.V.; Procaccio, V.; et al. Spectrum of pathogenic mtDNA mutations in Leber hereditary optic neuropathy families from Siberia. Genetika 2006, 42, 89-97. [PubMed] 
24. Nochez, Y.; Arsene, S.; Gueguen, N.; Chevrollier, A.; Ferre, M.; Guillet, V.; Desquiret, V.; Toutain, A.; Bonneau, D.; Procaccio, V.; et al. Acute and late-onset optic atrophy due to a novel OPA1 mutation leading to a mitochondrial coupling defect. Mol. Vis. 2009, 15, 598-608. [PubMed]

25. Behar, D.M.; van Oven, M.; Rosset, S.; Metspalu, M.; Loogväli, E.L.; Silva, N.M.; Kivisild, T.; Torroni, A.; Villems, R. A “Copernican” reassessment of the human mitochondrial DNA tree from its root. Am. J. Hum. Genet. 2012, 90, 675-684. [CrossRef]

26. van Oven, M.; Kayser, M. Updated comprehensive phylogenetic tree of global human mitochondrial DNA variation. Hum. Mutat. 2009, 30, E386-E394. [CrossRef]

27. Brandon, M.C.; Lott, M.T.; Nguyen, K.C.; Spolim, S.; Navathe, S.B.; Baldi, P.; Wallace, D.C. MITOMAP: A human mitochondrial genome database-2004 update. Nucleic Acids Res. 2005, 33, D611-D613. [CrossRef]

28. Ingman, M.; Gyllensten, U. mtDB: Human Mitochondrial Genome Database, a resource for population genetics and medical sciences. Nucleic Acids Res. 2006, 34, D749-D751. [CrossRef]

29. Attimonelli, M.; Accetturo, M.; Santamaria, M.; Lascaro, D.; Scioscia, G.; Pappada, G.; Russo, L.; Zanchetta, L.; Tommaseo-Ponzetta, M. HmtDB, a human mitochondrial genomic resource based on variability studies supporting population genetics and biomedical research. BMC Bioinformatics 2005. [CrossRef]

30. Li, B.; Krishnan, V.G.; Mort, M.E.; Xin, F.; Kamati, K.K.; Cooper, D.N.; Mooney, S.D.; Radivojac, P. Automated inference of molecular mechanisms of disease from amino acid substitutions. Bioinformatics 2009, 25, 2744-2750. [CrossRef]

31. Pejaver, V.; Urresti, J.; Lugo-Martinez, J.; Pagel, K.A.; Lin, G.N.; Nam, H.; Mort, M.; Cooper, D.N.; Sebat, J.; Iakoucheva, L.M.; et al. MutPred2: Inferring the molecular and phenotypic impact of amino acid variants. bioRxiv 134981. [CrossRef]

32. Adzhubei, I.A.; Schmidt, S.; Peshkin, L.; Ramensky, V.E.; Gerasimova, A.; Bork, P.; Kondrashov, A.S.; Sunyaev, S.R. A method and server for predicting damaging missense mutations. Nat. Methods 2010, 7, 248-249. [CrossRef] [PubMed]

33. Choi, Y.; Sims, G.E.; Murphy, S.; Miller, J.R.; Chan, A.P. Predicting the functional effect of amino acid substitutions and indels. PLoS ONE 2012, 7, e46688. [CrossRef] [PubMed]

34. Kumar, P.; Henikoff, S.; Ng, P.C. Predicting the effects of coding non-synonymous variants on protein function using the SIFT algorithm. Nat. Protoc. 2009, 4, 1073-1081. [CrossRef] [PubMed]

35. Khusnutdinova, E.; Gilyazova, I.; Ruiz-Pesini, E.; Derbeneva, O.; Khusainova, R.; Khidiyatova, I.; Magzhanov, R.; Wallace, D.C. A mitochondrial etiology of neurodegenerative diseases: Evidence from Parkinson's disease. Ann. NY Acad. Sci. 2008, 1147, 1-20. [CrossRef] [PubMed]

36. Mackey, D.; Howell, N. A variant of Leber hereditary optic neuropathy characterized by recovery of vision and by an unusual mitochondrial genetic etiology. Am. J. Hum. Genet. 1992, 51, 1218-1228. [PubMed]

37. Abu-Amero, K.K.; Bosley, T.M. Mitochondrial abnormalities in patients with LHON-like optic neuropathies. Invest. Ophthalmol. Vis. Sci. 2006, 47, 4211-4220. [CrossRef]

38. Gutierrez Cortes, N.; Pertuiset, C.; Dumon, E.; Borlin, M.; Hebert-Chatelain, E.; Pierron, D.; Feldmann, D.; Jonard, L.; Marlin, S.; Letellier, T.; et al. Novel mitochondrial DNA mutations responsible for maternally inherited nonsyndromic hearing loss. Hum. Mutat. 2012, 33, 681-689. [CrossRef]

39. Howell, N.; Oostra, R.J.; Bolhuis, P.A.; Spruijt, L.; Clarke, L.A.; Mackey, D.A.; Preston, G.; Herrnstadt, C. Sequence analysis of the mitochondrial genomes from Dutch pedigrees with Leber hereditary optic neuropathy. Am. J. Hum. Genet. 2003, 72, 1460-1469. [CrossRef]

40. Aitullina, A.; Baumane, K.; Zalite, S.; Ranka, R.; Zole, E.; Pole, I.; Sepetiene, S.; Laganovska, G.; Baumanis, V.; Pliss, L. Point mutations associated with Leber hereditary optic neuropathy in a Latvian population. Mol. Vis. 2013, 19, 2343-2351.

41. Rosenberg, T.; Norby, S.; Schwartz, M.; Saillard, J.; Magalhaes, P.J.; Leroy, D.; Kann, E.C.; Duno, M. Prevalence and Genetics of Leber Hereditary Optic Neuropathy in the Danish Population. Invest. Ophthalmol. Vis. Sci. 2016, 57, 1370-1375. [CrossRef]

42. Fraser, J.A.; Biousse, V.; Newman, N.J. The neuro-ophthalmology of mitochondrial disease. Surv. Ophthalmol. 2010, 55, 299-334. [CrossRef] [PubMed]

43. Tonska, K.; Kurzawa, M.; Ambroziak, A.M.; Korwin-Rujna, M.; Szaflik, J.P.; Grabowska, E.; Szaflik, J.; Bartnik, E. A family with 3460G $>$ A and 11778G $>$ A mutations and haplogroup analysis of Polish Leber hereditary optic neuropathy patients. Mitochondrion 2008, 5-6, 383-388. [CrossRef] [PubMed] 
44. Catarino, C.B.; Ahting, U.; Gusic, M.; Iuso, A.; Repp, B.; Peters, K.; Biskup, S.; von Livonius, B.; Prokisch, H.; Klopstock, T. Characterization of a Leber's hereditary optic neuropathy (LHON) family harboring two primary LHON mutations m.11778G >A and m.14484T>C of the mitochondrial DNA. Mitochondrion 2016, 36, 15-20. [CrossRef] [PubMed]

45. Behbehani, R.; Melhem, M.; Alghanim, G.; Behbehani, K.; Alsmadi, O. ND4L gene concurrent 10609T>C and 10663T $>C$ mutations are associated with Leber's hereditary optic neuropathy in a large pedigree from Kuwait. Br. J. Ophthalmol. 2014, 98, 826-831. [CrossRef]

46. Achilli, A.; Iommarini, L.; Olivieri, A.; Pala, M.; Hooshiar Kashani, B.; Reynier, P.; La Morgia, C.; Valentino, L.M.; Liguori, R.; Pizza, F.; et al. Rare primary mitochondrial DNA mutations and probable synergistic variants in Leber's hereditary optic neuropathy. PLoS One 2012, 7, e42242. [CrossRef]

47. Al-Kharashi, M.; Al-Kharashi, A.; Al-Obailan, M.; Kondkar, A.A.; Abu-Amero, K.K. Co-existence of m.10663T>C Mutation with Haplogroup L3f1b Background in a Patient with LHON. Can. J. Neurol. Sci. 2016, 43, 332-333. [CrossRef]

48. Yang, J.; Zhu, Y.; Tong, Y.; Chen, L.; Liu, L.; Zhang, Z.; Wang, X.; Huang, D.; Qiu, W.; Zhuang, S.; et al. Confirmation of the mitochondrial ND1 gene mutation G3635A as a primary LHON mutation. Biochem. Biophys. Res. Commun. 2006, 386, 50-54. [CrossRef]

49. Bi, R.; Zhang, A.M.; Jia, X.; Zhang, Q.; Yao, Y.G. Complete mitochondrial DNA genome sequence variation of Chinese families with mutation m.3635G >A and Leber hereditary optic neuropathy. Mol. Vis. 2012, 18, 3087-3094.

50. Hudson, G.; Carelli, V.; Spruijt, L.; Gerards, M.; Mowbray, C.; Achilli, A.; Pyle, A.; Elson, J.; Howell, N.; La Morgia, C.; et al. Clinical expression of Leber hereditary optic neuropathy is affected by the mitochondrial DNA-haplogroup background. Am. J. Hum. Genet. 2007, 81, 228-233. [CrossRef]

51. Ghelli, A.; Porcelli, A.M.; Zanna, C.; Vidoni, S.; Mattioli, S.; Barbieri, A.; Iommarini, L.; Pala, M.; Achilli, A.; Torroni, A.; et al. The background of mitochondrial DNA haplogroup J increases the sensitivity of Leber's hereditary optic neuropathy cells to 2,5-hexanedione toxicity. PLoS ONE 2009, 4, e7922. [CrossRef]

52. Wallace, D.C. The mitochondrial genome in human adaptive radiation and disease: On road to therapeutics and performance enhancement. Gene 2005, 354, 169-180. [CrossRef] [PubMed]

53. Wallace, D.C. Mitochondrial DNA Variation in Human Radiation and Disease. Cell 2015, 163, 33-38. [CrossRef] [PubMed]

54. Lui, Z.; Song, Y.; Li, D.; He, X.; Li, S.; Wu, B.; Wang, W.; Gu, S.; Zhu, X.; Wang, X.; et al. The novel mitochondrial 16S rRNA 2336T>C mutation is associated with hypertrophic cardiomyopathy. J. Med. Genet. 2014, 51, 176-184. [CrossRef]

55. Verechshagina, N.; Nikitchina, N.; Yamada, Y.; Harashima, H.; Tanaka, M.; Orishchenko, K.; Mazunin, I. Future of human mitochondrial DNA editing technologies. Mitochondrial DNA A DNA Mapp. Seq. Anal. 2019, 30, 214-221. [CrossRef]

(C) 2019 by the authors. Licensee MDPI, Basel, Switzerland. This article is an open access article distributed under the terms and conditions of the Creative Commons Attribution (CC BY) license (http://creativecommons.org/licenses/by/4.0/). 